\title{
Factors affecting the suckering of trembling aspen
}

\author{
G. A. STENEKER
}

Northern Forest Research Centre

Canadian Forestry Service

Edmonton, Alberta

Suckering of trembling aspen (Populus tremuloides Michaux) has been attributed to a number of stimuli. Factors such as light (Stoeckeler 1960) and increased soil aeration (Weigle and Frothingham 1911) after cutting, have been suggested as causes for sucker initiation. It is now generally accepted that the apical dominance phenomenon (Farmer 1962) and soil temperature (Maini and Horton 1966a) play the essential roles in the formation and development of suckers on aspen roots. Farmer (1962) suggested that the interruption of the flow of growth regulators from the tree crowns to the roots is required for sucker formation, whereas Maini and Horton (1966a) concluded that exposure of the roots to adequate temperatures can by itself cause suckering and that suckers may occur on roots of trees that have not been disturbed.

In 1969 a field study was initiated to assess the importance of the apical dominance effect and temperature upon sucker formation on trembling aspen roots.

\section{Methods}

Six blocks were laid out in a 12-year-old trembling aspen stand in Riding Mountain National Park, Manitoba, in June 1969. Dominant tree height was $18 \mathrm{ft}(5.5 \mathrm{~m})$ and stem diameter at breast height averaged 2.0 inches $(5 \mathrm{~cm})$. Stocking ranged from 5000 to 6000 trees per acre $(12000-15000 /$ ha $)$. Within each block four $10 \times 10-\mathrm{ft}(3 \times 3 \mathrm{~m})$ sample plots were established and each plot was randomly assigned one of the four following treatments:

$1 /$ Trenching only: one trench ( 6 inches -15 $\mathrm{cm}$ - deep) around the plot boundary and two trenches within the plot at right angles to each other, dividing the plot in four equal squares. The objective of the treatment was to break the apical dominance effect in the lateral roots near the surface without raising the soil temperature.

2/Bending of trees: careful removal from the plot through cutting and clipping of all vegetation other than aspen so as to cause minimal disturbance
Facteurs responsables de la formation des rejets de souche chez le peuplier faux-tremble. Une augmentation de la température du sol seule n'entrainera pas la formation de rejets de souche dans un peuplement de 12 ans de peuplier faux-tremble. La coupe des racines effectuée par le creusage de tranchées appropriées n'affecta pas la température du sol mais augmenta de façon significative les rejets de souche. L'auteur conclut alors que l'influence de la dominance apicale de la cime de l'arbre et non de la température du sol contrôle la formation des rejets. Une fois cette dominance apicale brisée, la température augmentée du sol aidera à cette formation de rejets. to soil and residual roots and the bending back of residual trees to expose the soil surface to direct sunlight. Objective of the treatment was to increase soil temperatures without breaking the apical dominance effect of the tree crowns.

$3 /$ Cutting and trenching: cutting of all aspen and other vegetation and trenching as described unter treatment 1 . Objective of the treatment was to increase soil temperatures and break the apical dominance effect.

4/Control: no treatment.

Neighboring plots were a minimum of $60 \mathrm{ft}$ $(18 \mathrm{~m})$ apart and probably contained trees of different clones. Because of their flexibility and size, trees were easy to bend and direct sunlight reached most of the ground surface on the plots receiving treatment 2 .

To measure soil temperatures in the vicinity of lateral aspen roots, all plots in two blocks were divided into 16 equal squares. A maximum thermometer was placed in the humus layer $\left(A_{0}\right)$ just below the surface $(2 \mathrm{~cm})$ in a square on each of the eight plots. From July 25 to August 19 maximum daily temperatures were recorded, the thermometer reset and moved to the next square in the plot in such a way that over a 16-day period all squares on each plot were sampled. Since all plots were oriented the same way the eight thermometers on any one day were placed in identical squares (e. g. first square in NW corner, etc.).

In conjunction with the investigation at Riding Mountain National Park, all trees from five separate trembling aspen clones in a 35-year-old stand at Agassiz Forest Reserve, Manitoba, were cut in June. All ground vegetation was also removed and care was taken to cause the least possible disturbance to the soil surface. The five resulting openings were 15 to $20 \mathrm{ft}(4.5$ to $6 \mathrm{~m})$ in diameter and several hundred feet apart. Since excavations I had done earlier showed that the root systems of different clones freely intermix, I assumed that roots of bordering uncut clones also occurred within each opening. Therefore, the roots of both cut and uncut clones would be exposed to increased soil temperatures. 
In August of the same year all first-year suckers in the $10 \times 10-\mathrm{ft}$ plots and the five openings at Agassiz Forest Reserve were tallied.

\section{Results}

Maximum daily soil temperatures in the $A_{0}$ layer following the bending and cutting-and-trenching treatments did not differ significantly during the observation period and averaged $78^{\circ} \mathrm{F}-25.5^{\circ} \mathrm{C}-$ (Table 1).. Both treatments resulted in soil temperatures within the $75^{\circ}-85^{\circ} \mathrm{F}\left(23.9^{\circ}-29.4^{\circ} \mathrm{C}\right)$ range, considered by Maini and Horton (1966b) to be excellent for sucker production. Maximum soil temperatures on the control and trenched-only plots wer significantly lower $(P<.01)$ than those following the other two treatments and averaged $66.5^{\circ} \mathrm{F}$ $\left(19.2^{\circ} \mathrm{C}\right)$ over the same period.

TABLE 1. Average daily maximum temperatures $2 \mathrm{~cm}$ below the soil surface following four different treatments (Period of observation: 25 July to 19 August 1969)

\begin{tabular}{|c|c|c|}
\hline Treatment & $\begin{array}{c}\text { Temperature } \\
\left({ }^{\circ} \mathbf{F}\right) \pm \mathbf{S E}\end{array}$ & $\begin{array}{c}\text { Coeff. } \\
\text { variation } \\
(\%)\end{array}$ \\
\hline $\begin{array}{l}\text { Control................ } \\
\text { Trenching only .......... } \\
\text { Bending. .............. } \\
\text { Cutting and trenching... }\end{array}$ & $\begin{array}{l}65.0 \pm 1.05 \\
67.7 \pm 1.08 \\
78.7 \pm 1.81 \\
77.3 \pm 1.72\end{array}$ & $\begin{array}{l}6.8 \\
6.7 \\
9.7 \\
9.5\end{array}$ \\
\hline
\end{tabular}

An analysis of variance indicated a significant $(P<.05)$ treatment effect upon sucker production and a subsequent Studentized Range test indicated significant $(\mathrm{P}<.05)$ differences between all except the control and bending treatments (Table 2). The cutting-and-trenching treatment gave by far the highest production (211 suckers).

Morphological features of the foliage of first-year suckers in the openings at Agassiz Forest Reserve were used to differentiate between clones. In three of the five openings suckers occurred only from the cut clone. In the other two openings, suckers from other clones were also found but their number

TABLE 2. Number of first-year trembling aspen suckers on differently treated $10 \times 10$-ft sample plots in a 12-yearold aspen stand

Treatment

\section{Cutting}

Replication Control Bending Trenching trenching

\begin{tabular}{ccrrr}
1 & 0 & 0 & 11 & 23 \\
2 & 3 & 2 & 14 & 32 \\
3 & 2 & 3 & 3 & 51 \\
4 & 0 & 0 & 4 & 43 \\
5 & 0 & 6 & 12 & 34 \\
6 & 0 & 0 & 4 & 28 \\
\hline $\begin{array}{c}\text { Total } \\
\text { Average }=\end{array}$ & 5 & 11 & 48 & 211 \\
$\Sigma \frac{\sqrt{\mathrm{X}+1}}{6}$ & $1.29 \mathrm{a}^{1}$ & $1.56 \mathrm{a}$ & $2.90 \mathrm{~b}$ & $5.96 \mathrm{c}$
\end{tabular}

Studentized range $\mathrm{D}=1.16$

${ }^{1}$ Values not followed by same letter are significantly different $(\mathrm{P}<.05)$ did not exceed $30 \%$ of the total number of firstyear suckers.

\section{Discussion}

Suckering on the $10 \times 10$-ft sample plots at Riding Mountain National Park suggests that apical dominance effect primarily controls suckering. Where the aspens had been bent back, temperatures in the upper soil horizons reached levels (average of $78^{\circ} \mathrm{F}$ $-25.5^{\circ} \mathrm{C}$ ) which were excellent for sucker formation. However, suckering was negigible, presumably because the apical dominance effect of the crowns had not been broken. On the other hand, the trenching-only treatment stimulated suckering although soil temperatures had not been changed from undisturbed conditions. The cutting-andtrenching treatment probably released many more roots from the apical dominance effect than the trenching-only treatment. This may explain why the former produced approximately four times as many suckers. Furthermore, soil temperatures on the cutand-trenched plots reached approximately $10^{\circ} \mathrm{F}$ higher than on the trenched-only plots. This may also have contributed to the larger number of suckers following the former treatment.

At Agassiz Forest Reserve suckering in the five openings from the roots of trees other than those that had been cut, was scarce or non-existing. However, soil temperatures in the openings must have been adequate for suckering.

In conclusion, the results suggest that the apical dominance effect of the tree crowns primarily controls suckering. Once this effect is broken, increased soil temperatures will promote suckering.

\section{Management implications}

Aspen clones can vary in growth rate (Zahner and Crawford 1965) and quality (Wall 1969). Therefore consideration may be given to management techniques that will reduce the number of inferior clones in a stand in favor of faster growing and better quality clones. Such stand improvement could be achieved by:

- Selective cutting to remove inferior clones a few years before the final cut. Such cutting will result mainly in sucker regeneration from the cut clones. A subsequent final cut removing residuals and young suckers will result in vigourous sucker production from the roots of good quality residuals but less vigorous regeneration is expected from the clones previously cut.

- Cutting only of good quality clones at harvest time. Some suckering of the uncut trees will occur, because damage to the roots of these trees, due to logging, is inevitable. With the last approach there is a danger that the ground surface will not be adequately exposed to direct sunlight if too many trees are left standing, or if ground vegetation is heavy. Regeneration from the cut clones and its subsequent development would thus be hindered. Local stand conditions and configuration of clones should govern what technique is best to apply. 


\section{References}

FARMER, R. W. Jr. 1962. Aspen root sucker formation and apical dominance Forest Sci. 8:403-410.

GRAHAM, S. A., R. P. HARRISON Jr. and C. F. WESTALL Jr. 1963. Aspens - Phoenix trees of the Great Lake region. Univ. Michigan Press, Ann Arbor. xiii +272 p.

MAINI, J. S. and K. W. HORTON. 1966a. Reproductive response of Populus and associated Pteridium to cutting, burning and scarification. Can. Dep. Forest. Rural Dev. Forest. Br. Publ. No. 1155. 20 p.

-1966b. Vegetative propagation of Populus spp. 1 Influence of temperature on formation and initial growth of aspen suckers. Can. J. Bot. 44:1183-1189.
STOECKELER, J. H. 1960. Soil factors affecting the growth of quaking aspen forests in the Lake States. Univ. Minn. Agr. Exp. Sta. Tech. Bull. No. 233. 48 p.

WALL, R. E. 1969. Distribution of Fomes igniarius in aspen stands as affected by clonal variation. Can. Dep. Fish. Forest. Bi-monthly Res. Notes 25(1):5.

WEIGLE, W. G. and E. H. FROTHINGHAM. 1911. The aspens - their growth and management. US Dep. Agr. Forest Serv. Bull. No. 93. 35 p.

ZAHNER, R. and N. A. CRAWFORD. 1965. The clonal concept in aspen site relations, p. 230-243. In C. T. Youngberg (ed.) Forest-soil relationships. Oregon State Univ. Press, Corvallis, Ore.,

\section{FURESTERS

CUSO has received requests for foresters to work in the Forest Research Institute and the Forest Department Headquarters in West Malaysia.

Forest Management - to coordinate assessment of the logged-over forests and prepare plans for forest development.

Forestry Statistics - to plan, organize and carry out the analysis of forest inventory data.

Timber Technology - to $\mathrm{plan}$ and undertake research in structural utilization of Malaysian timber.

Paper Technology - to assist in the pulping of mixed tropical hardwoods, and to carry out bleaching experiments.

CUSO also has requests for foresters in Cuba, Central America and Africa. Positions are for 2 years and salaries generally are paid by the host country at the local wage. CUSO provides return travel, orientation and medical coverage.

For further information write:

CUSO Recruitment R.5, 151 Slater Street. 